\title{
KNOWLEDGE-BASED SUSTAINABLE DEVELOPMENT \\ - CONTEMPORARY USE OF COMMUNIST-ERA URBAN DEVELOPMENTS IN THE CENTRES OF ROMANIAN CITIES
}

\author{
Horia Mihai Coman ${ }^{1}$
}

DOI: https://doi.org/10.31410/ERAZ.2019.325

\begin{abstract}
Romania, as other neighbouring countries, has been under a socialist-communist regime since the end of the Second World War, until 1989. From King Michael I's forced abdication of 1947, until the Romanian revolution of 1989, the socialist-communist authorities have been laying their marks on the country, including some extensive urban developments in the centres of many Romanian cities. These developments were often carried out through a considerable amount of demolition works, thus replacing older buildings - and pre-communist built areas - with new ones. Consequently, many Romanian cities ended up losing elements of architectural heritage, memory and identity. Old mansions, churches or merchant houses usually had to leave the scene in order for a new architecture to emerge - one that would be mostly rooted in functionalism, brutalism and socialist modernism.
\end{abstract}

Today, at roughly 30 years since the fall of communism, some communist-era urban developments are beginning to "age", as some of the buildings erected in that era began to require repair works and different means of upgrade, such as thermal insulation. This triggers some actions of architectural remodeling of communist-era buildings, and even some urban remodeling of communist-era civic centres and urban ensembles. Looking at how these actions are being done, one of the most immediate remarks has to do with the fact that the original designs of the buildings and urban spaces are often modified, altering their "personality". In other cases, communist-era urban developments that occupy portions of the city centres are beginning to decay, laying in a somewhat semi-abandoned state, probably not popular with city dwellers...while older parts of the central areas are bustling with city life. This phenomenon raises the problem of "sustainable development" regarding this family of urban areas, as they are often linked with bad memories of the communist past, triggering a mix of neglect and desire to modify (in looks, in form).

Following this setting, the paper tries to analyse the reasons behind this phenomenon, also searching for ways in which these (often unpopular) communist-era developments can be approached in order to properly use the central areas that they occupy, in a sustainable manner.

One of the key findings of the research has to do with issues of identity, as perceived by the public. Lack of attachment to communist-era urban developments from central areas is strongly linked to the destructions that made the new developments possible, in the beginning. In order to gain a higher degree of appreciation and interest from the public, these developments usually strive for "upgrade", as a "rebirth" of personality. For example, many of the department stores have had their facades remodeled in recent years, and this visual "refresh" often brings more people to the stores. On the other hand, large mineral open spaces usually get "flooded" with vegetation in recent edilitary works - in order to (probably) make the former squares (initially designed for political rallies) a little more "humane". It seems like the identity of communist-era spaces and buildings is not too valuable for the communities they should serve and represent...

Keywords: rehabilitation, revamp, conservation.

Faculty of Architecture and Urban Planning, Technical University of Cluj-Napoca, Observatorului Street 72-76,400500, Cluj-Napoca, Romania 


\section{SUSTAINABILITY IN REGARD TO FUNCTIONALITY}

$\mathrm{O}$ ne focus of the research would be on the technical side, in order to evaluate the targeted "heritage" in terms of adaptation to current technical needs. In this respect, the thermal rehabilitation is a relevant example, as communist-era buildings (mostly blocks of flats) adapt to this new technical goal. Quite often, other technical aspects of the buildings tend to be improved, such as piping, but the thermal insulation is usually more striking, as it changes the exterior appearance (i.e. the facades) of the buildings.

Otherwise, communist-era buildings can be considered quite "young", at least in comparison with other "generations" of built heritage, such as the interwar-period modernism, the turn-ofthe-century architecture, or the $19^{\text {th }}$ century eclectic group. Inside the "communist family of built form" itself, some products are older and newer. In the area that constitutes the focus of this paper, namely communist-era buildings that are to be found in central areas of Romanian towns, one immediate observation can be stated: the newer buildings (1980s blocks of flats) and the more special ones (public buildings) usually tend to be preserved in their original form, with relatively few modifications, while older and more ordinary buildings (especially 1960s and 1970s blocks of flats) tend to pe modified in a more consistent and noticeable way.

As most 1960s and 1970s blocks of flats had been constructed as forms of social housing, using arguably poor materials (such as prefabricated concrete panels for facades), the trend is to upgrade such facades. This is usually done as thermal rehabilitation. On the other hand, the newer generations of blocks of flats, usually constructed after the 1977 earthquake with subsequent improved structural resistance and better construction materials (such as light cellular concrete bricks in the compositions of the walls), have been usually needing less renovation. As the exterior walls and the facades had usually been constructed using the cellular concrete bricks, these blocks of flats are performing better in terms of thermal insulation, compared to the ones that used thin prefabricated concrete panels. That is one of the leading reasons for which $1980 \mathrm{~s}$ blocks of flats have usually preserved their original facades, while the 1960s and 1970s blocks have usually been rehabilitated and thus modified.

The 1950s generation is a little bit more interesting, as the 1950s blocks of flats usually look "sturdier" than the 1960s and 1970s ones - with a more robust appearance, overall - compared to the "thin" look of the prefabricated facade panels that came to be largely used in the 1960s and 1970s. The 1950s are the years of the aesthetics of the "socialist realism" (sometimes written with capital letters or labelled as "Stalinism"), when blocks of flats were usually conceived as "palaces for the working class", wanting to offer quality and prestige to the working class, as to compensate for the frustration of the proletariat's former condition as people who could not afford quality housing. [1]. Following the popular slogan of "giving columns to the working class", the 1950s blocks of flats usually employed some decoration in the form columns and pilasters. Because of all these reasons, 1950s blocks of flats and ensembles are often preserved in their original form, quite rarely being affected by the "polystyrene frenzy" (from a rough statistical viewpoint). Decoration may be an important reason for this, as communist-era blocks of flats are, retrospectively, largely devoid of decoration. After the fall of communism and because of the subsequent restauration of the basic freedom of speech, most communist-era apartment buildings have begun to be often described as mere "matchboxes". Consequently, the blocks of flats that do retain some decoration may be seen as something valuable, lowering the chance of them being "polystyrenised", although being quite old... 
The aforementioned tendency to preserve communist-era decoration on buildings (when it is the case) can also be noticed when talking about the contemporary uses of many "special" public buildings from the era, such as administrative centers (town halls) or cultural centers (the "houses of culture", as they were called). Being usually decorated and having more complex designs in terms of volumes, it can be speculated that these buildings have been less prone to post-communist rehabilitation, because of a few reasons. Hotels and department stores have usually had a somewhat different fate. As private-owned businesses that had to modernise in order to survive and thrive on the free market in post-communist times, they were prone to more frequent rehabilitation works than state-owned public buildings.

The ecological aspect of sustainability is another issue. Regarding this, it can be argued that some large public buildings from the time of communism are hardly sustainable because of relatively high operating costs (heating, air conditioning, etc.) and relatively high carbon footprints, even if their functionality is not considerably affected. Again, sustainability is a complex concept, so the task of evaluating a building's overall performance in sustainability is also complex.

\section{SUSTAINABILITY IN REGARD TO SEISMIC RISK}

Regarding this paper's target group of architectural and urban heritage, another important aspect of sustainability would be earthquake risk. Bucharest, for example, is one of Europe's most dangerous cities in terms of destruction related to earthquake risk, as massive earthquakes (around 7 on the Richter scale) usually occur once in a couple of decades. The usual epicenter of these earthquakes is in the Vrancea region, approx. $150 \mathrm{~km}$ from Bucharest, to the North-East. The last disastrous Vrancea-type earthquake happened in 1977, its magnitude being measured to 7.2 on the Richter scale. It claimed the lives of approx. 1.500 people and it injured around 11.000 others, circa $90 \%$ of the casualties being in Bucharest. Some dozens of buildings collapsed in the capital city. Before this, another massive earthquake was recorded in 1940. It was measured to 7.4 Richter [2].

Consequently, an important quantity of buildings is in danger of collapsing at the next big earthquake. Communist-era buildings from the central areas are no exception to this. The most vulnerable group from the socialist-communist heritage is that of high-rise (and sometimes medium-rise) apartment blocks that were built in the early years of socialist-communist rule, before the 1977 earthquake, so roughly between 1947 and 1977. Following the disaster of 1977, seismic design of buildings substantially evolved, but seismic considerations were relatively scarce before 1977, although not completely absent.

This is one of the reasons for which this particular group of buildings is facing considerable sustainability issues, as the risk of collapse affects it in many ways. For example, the "Gioconda" high-rise apartment block in Bucharest has become mostly unsustainable for renovation works and upkeeping. While other neighbouring apartment blocks - that pose a lower collapse risk have been thermally rehabilitated and upgraded, the Gioconda tower is almost virtually "frozen in time" from when it was built, in the year 1959 [3]. The load-bearing structure of reinforced concrete has been consolidated only partially, as a complex system of causes and reasons have hindered the building's security agenda. One of these drawbacks is the difficulty of sustaining the potential cost of a structural consolidation, as state contribution to the expenses is usually hard to obtain due to complicated and slow bureaucracy, widespread corruption and even lack of concern towards the matter. As the "Gioconda" is technically a condominium, with every 
flat being owned by a private entity (usually residents), plus a few shops at ground level, a potential consolidation cannot be theoretically done if some of the owners refuse to contribute to the expenses. As some of the owners prefer not to invest money in the building's consolidation, the work cannot be done. Some of the residents are often caught in the situation of wanting to contribute, but not having the funds that are required, due to relatively low income. Because of this, public funding or sponsorships are usually sought after, but, as they rarely materialise, the owners of the flats prefer to stick to their properties, accepting the threat in case of a devastating earthquake.

Another potential solution to the problem theoretically exists, but its chances of success have also proven to be quite low. It's the practice of state-funded compensation for a private property that needs to be demolished because of various reasons. In this situation, the high risk of collapse can be easily considered as a risk to public safety, thus the structure can be designated to be demolished. In order for this to happen though, each private owner has to accept the offered compensation, and this is usually in the form of money or another flat in a new building, usually at the outskirts of the city. As the Gioconda block is in the core of Bucharest's city center, some owners refuse to move or accept the money from the state, as they don't consider the compensation to be fair, or to suit their needs and interests. In this situation, it is usually quite hard for the authorities to force the owners into accepting the compensations, if they refuse to...and this is due to the specific features of Romanian property law and urban development law, alongside the quite difficult and slow bureaucracy, plus the relatively low performance and amplitude of state-induced urban development.

For all these reasons, the "Gioconda" tower block has become a low-quality and low-income condominium. Many of the former residents have rented their apartments and moved into a probably safer flat/house. Some "original" residents, living in the tower block since it was built in 1959, have aged and have probably found it hard to move away. Because of its seismic risk, the Gioconda's flats are cheaper to sell/rent than similar flats in nearby blocks that have a lower seismic risk. This theoretically attracts more low-income owners and tenants to the Gioconda, making it quite unsustainable to afford proper structural rehabilitation. The facade has not been rehabilitated, some original pieces of cladding materials have fallen, and the building is in a quite bad shape, overall.

Another clue to its difficult situation is the frequent use of huge advertising meshes on the facade. These meshes are blocking window views from the flats to the outside, but the owners of the flats receive money for accepting advertising on their part of the facade. It is interesting to realise that the residents choose to renounce a considerable amount of daylight and urban view in order to receive some money from advertisers. Arguably, this phenomenon is more unlikely to happen on the facades of higher-income apartment buildings, but it's affecting a considerable amount of city-center apartment buildings similar to the Gioconda, where seismic risk is taking its toll on the quality of life of the residents, through the downfall of the prices of property. On the other hand, an aspect that cannot be overlooked is the fact that the tower block has adapted, and that it is now providing more accessible prices for apartments in the heart of Bucharest's city center...Some of the spaces are momentarily being used by some homeless people. The relatively bad shape of the facades may be considered to have attracted a few manifestations of street art, as some murals (plus some graffiti) have made their way onto the surfaces of the building. How sustainable is the Gioconda block actually? Yet again, the sustainability issue presents itself as a relative, debatable and problematic aspect. 


\section{SUSTAINABILITY IN REGARD TO PERCEIVED CULTURAL VALUES AND IDENTITY}

Technical aspects such as functionality, carbon footprint or seismic risk may be some of the first ones to be considered when trying to explain and evaluate a certain building's sustainability performance. Apart from the more technical side, there is also an undeniable cultural side of sustainability, as well. The cultural perception of a building can play an important role in its sustainability, and this can happen in many ways. For example, the cultural attachment of certain groups of people to certain buildings tends to work in favour of those buildings' conservation and upkeep, and this can be considered as a form of (cultural) sustainability. On the other hand, buildings and spaces that are not so culturally relevant for a specific community, and have not triggered consistent attachment from the part of the citizens, are more prone to changes and alterations to their integrity. As in heritage protection law and practice, higher cultural values attract higher degrees of required conservation of those values, while lower cultural values leave more space for changes to the original, existing forms. Different categories of (cultural) values can be either the product of professional evaluation, as it happens with listed monuments and sites, or they can be the product of the unqualified perception of regular citizens and groups - and this can be observed in the way that groups of citizens relate to their built environment in terms of preservation of the original designs.

Therefore, cultural insight can also prove to be a useful tool in understanding the ways in which urban developments from the socialist-communist period are being used and edited today. For example, the building of the National Theatre of Craiova (a communist-era building that was designed and erected between 1969 and 1974) [4] is often perceived as a cultural value, having succeeded in earning an unusual status of "unofficial monument" in its "community" (the people of Craiova, here considered as a "collectivity", from a sociological/anthropological point of view). Relatively new buildings and communist-era ones are rarely perceived as cultural values, and they are very rarely listed as protected heritage inside the Romanian law - thus turning the National Theatre building of Craiova into a special case.

Although it is not listed as heritage, so not technically a "monument", the theatre building is often labelled as such by various citizens of Craiova and beyond, including some leading architects and intellectuals. The generally perceived - and often stated - architectural/cultural value of the building makes it an icon and (arguably) a symbol of the city, although Romanian law does not (yet) recognize it as such.

In return, this acclaimed cultural value of the Craiova theatre building may be considered as one of the reasons for which it has not been altered (in its original architectural design) following the fall of communism. The value of this particular theatre building largely rests on its perceived architectural qualities, mostly due to its special composition of volumes. This sets the Craiova theatre building apart from usual communist-era buildings - often labelled as dull, austere, common, severe, stern, etc. Therefore, in this chain of explanations, one can notice a "red wire" travelling between good architectural design, perceived cultural value, identity, conservation, and sustainability. 


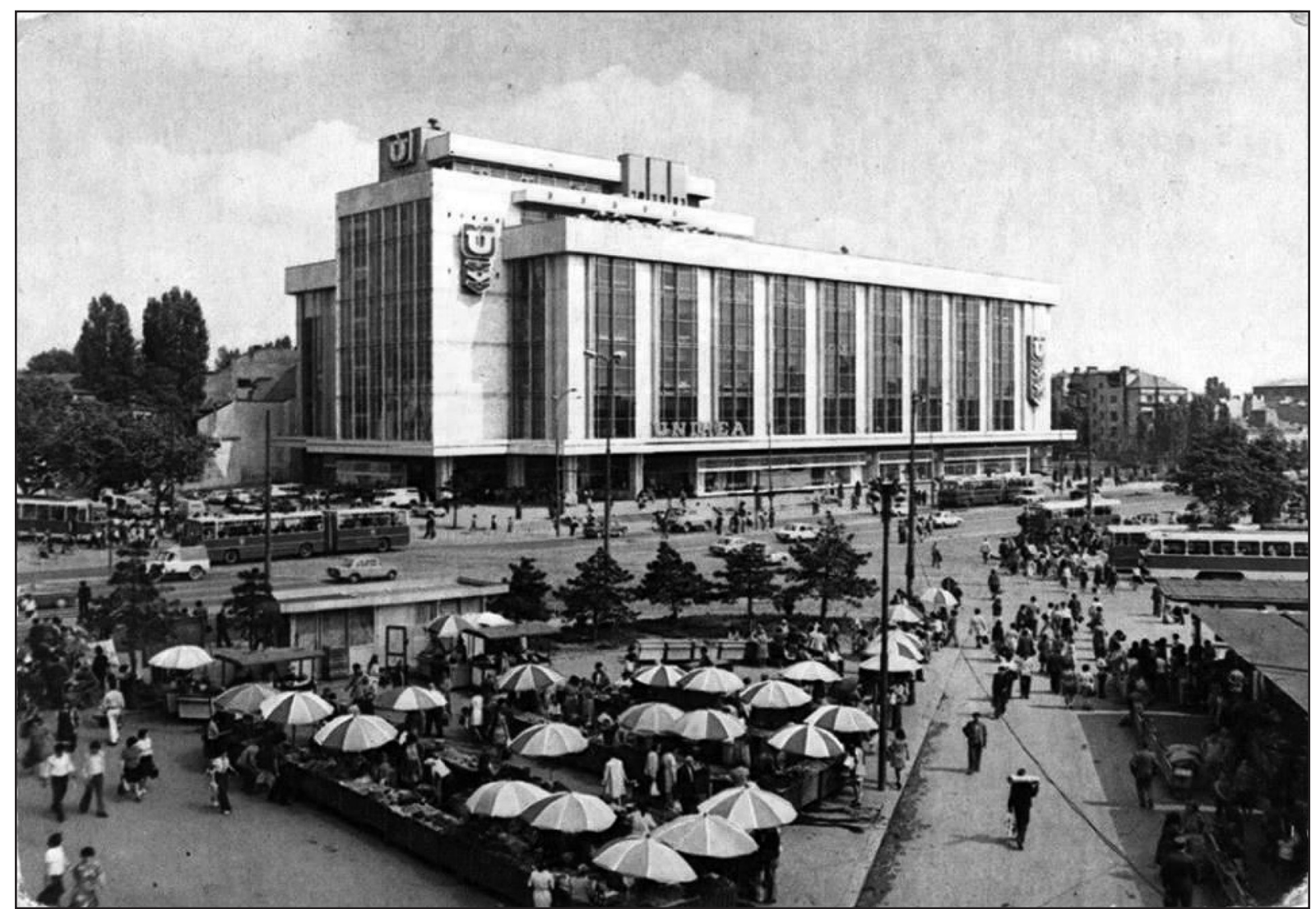

Figure 1: "Unirea" Universal Store, Bucharest: the first wing of the store, built 1976. It was to be later extended, with 2 adjoining wings, during the 1980s.

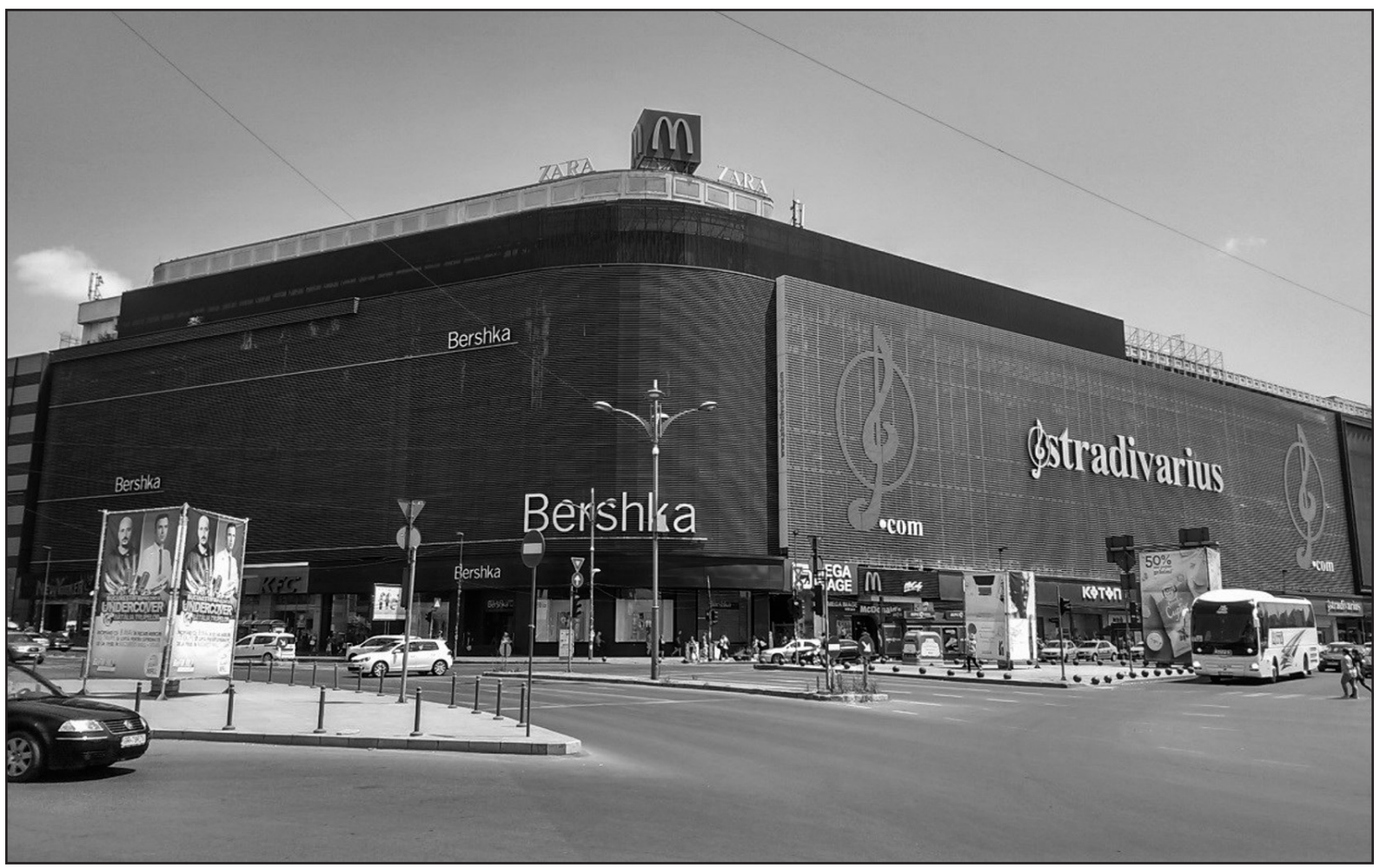

Figure 2: former "Unirea" Universal Store (Bucharest) in its current form, renamed "Unirea Shopping Center". The new facade is covering the original one. There have been several changes in the appearance of the facade since the end of the socialist-communist era. 


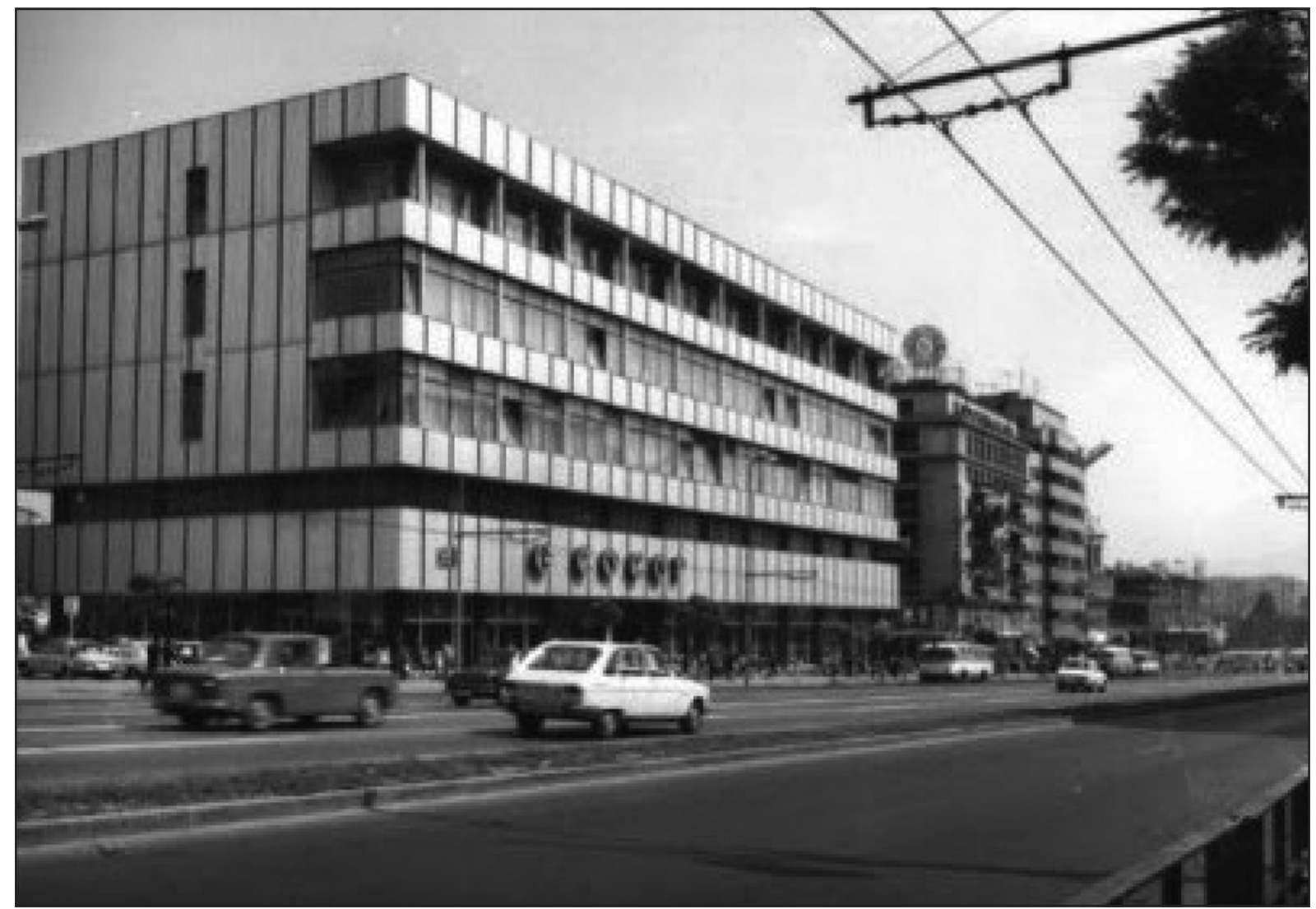

Figure 3: "Cocor" Universal Store, Bucharest, in its original form (built in the 1970s).

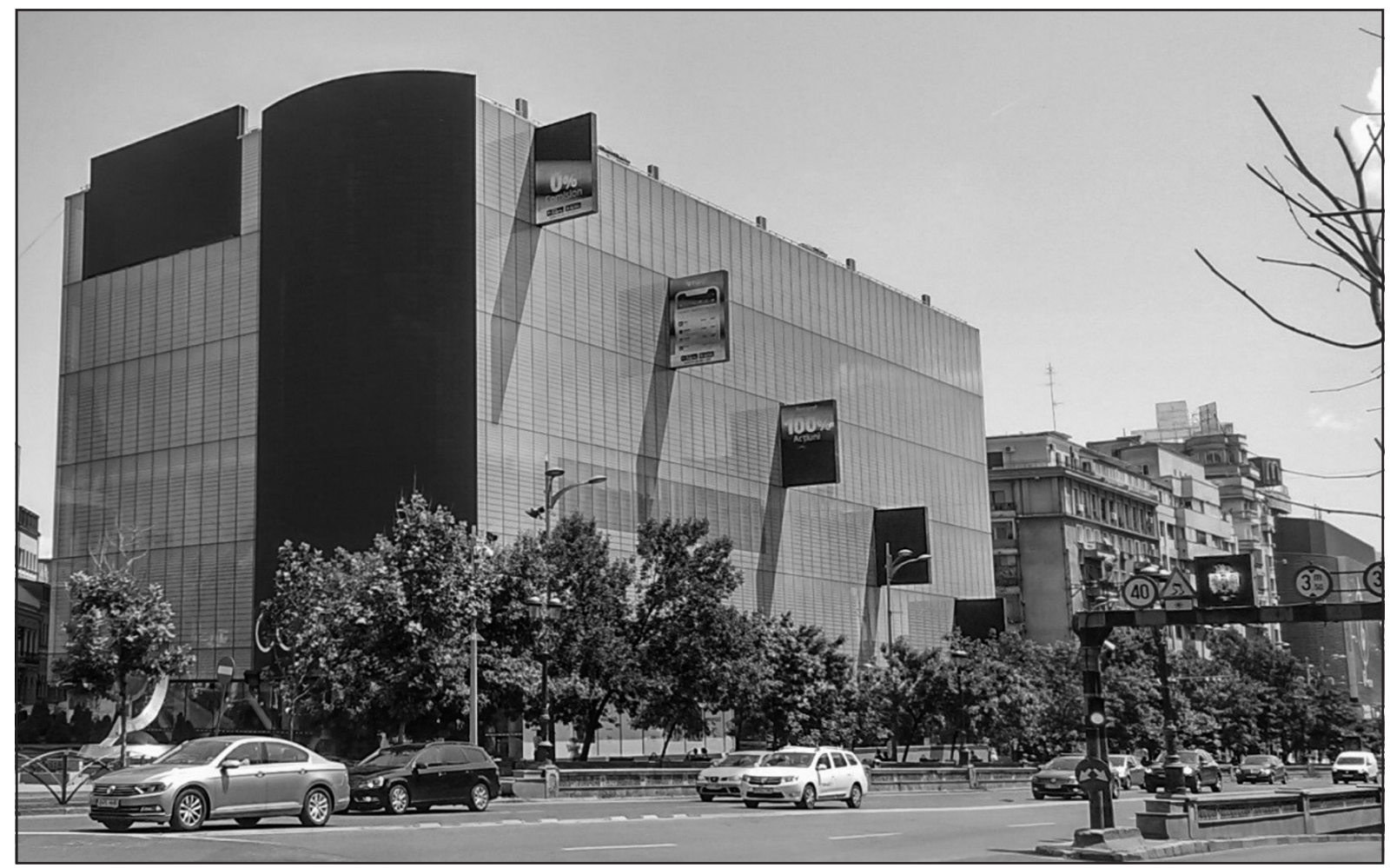

Figure 4: the "Cocor" store (Bucharest) in its current form, rebranded as luxury store and displaying multimedia facade. The picture is taken from the same approximate angle as the communist-era one. 


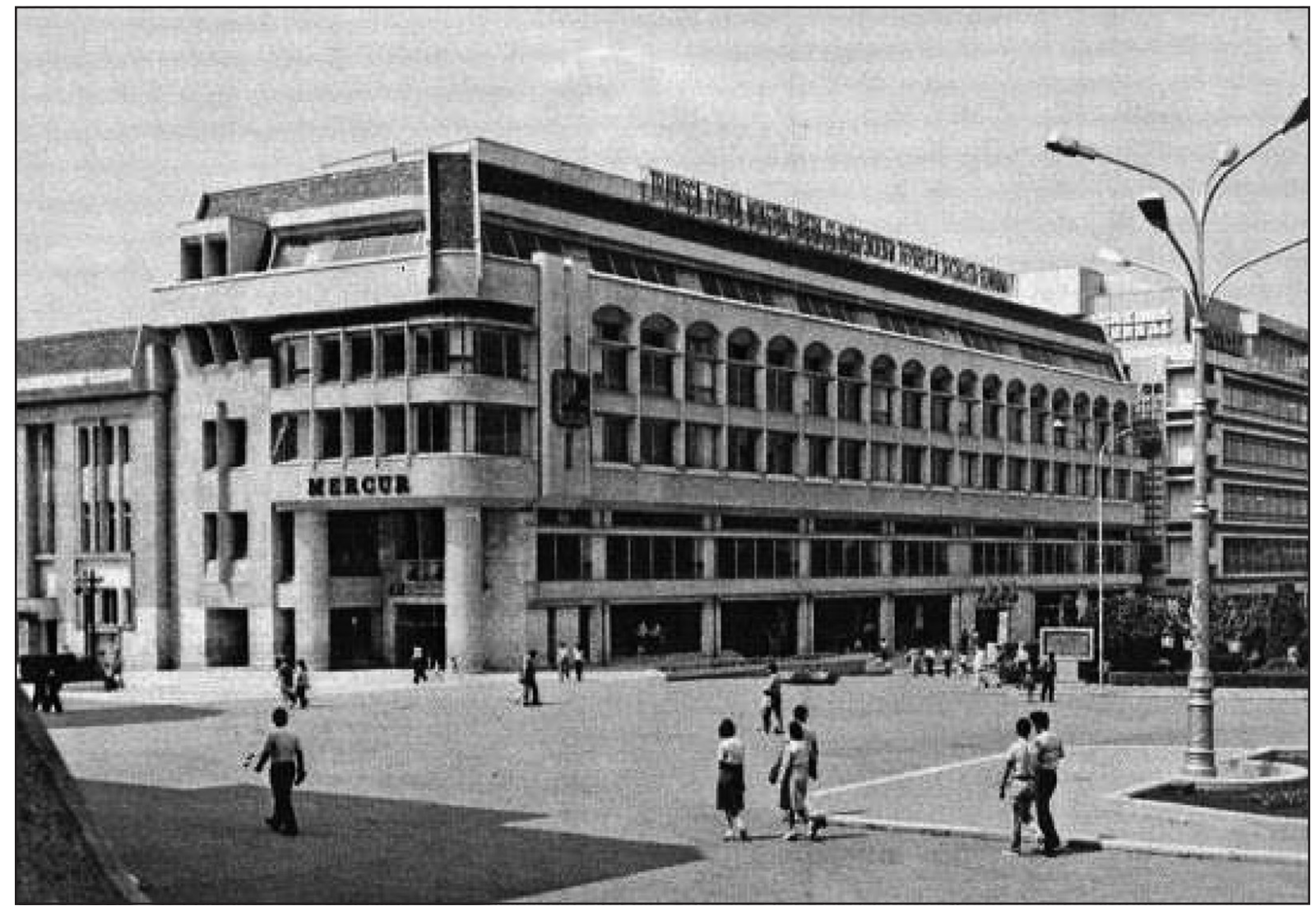

Figure 5: "Mercur" Universal Store, Craiova, in its original appearance, from the 1980s.

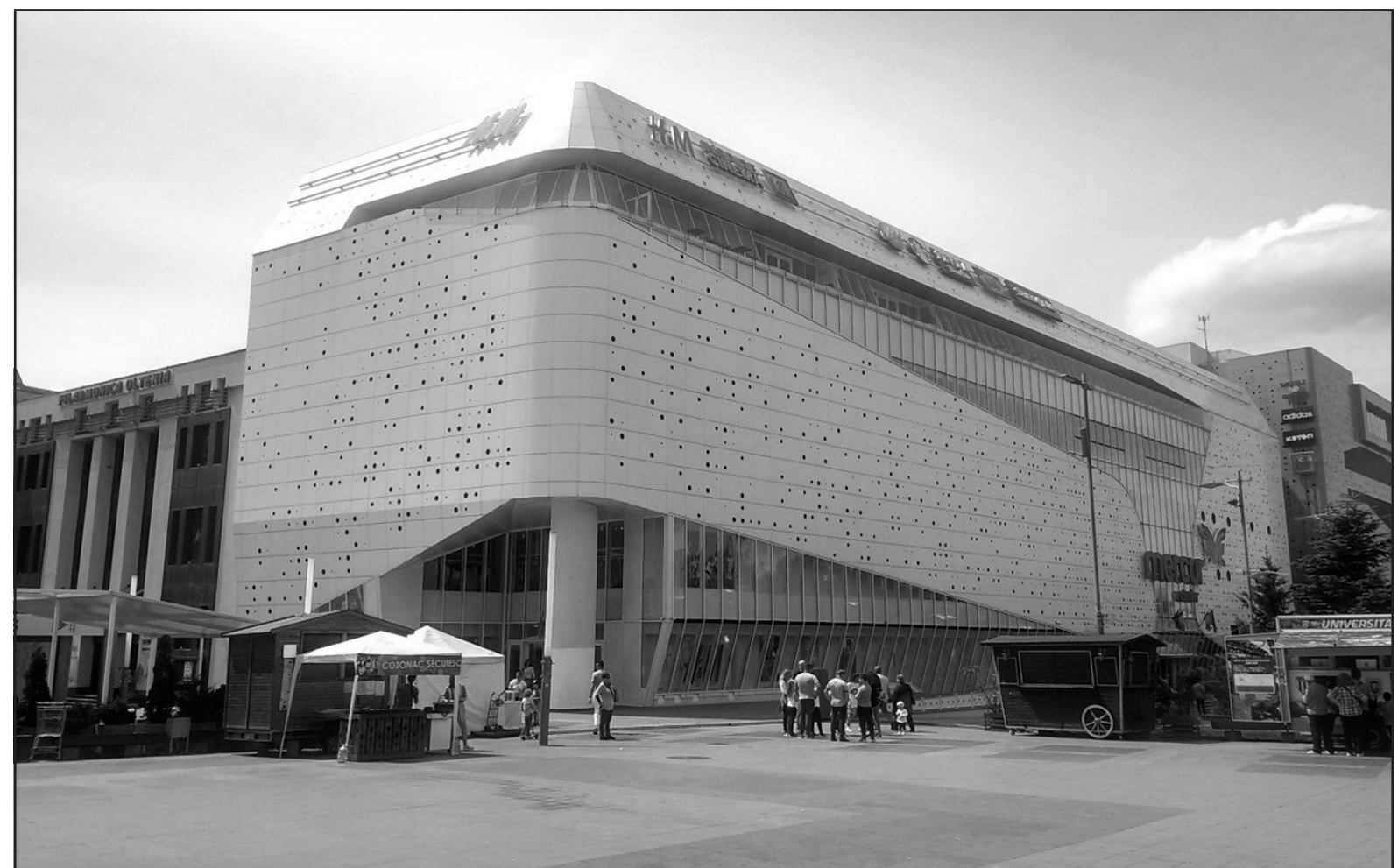

Figure 6: the new "Mercur" store (Craiova), consistently revamped (in 2015), renamed "Mercur Center", and transformed into a mall (by today's standards). The facade is strikingly modern, and has been largely acclaimed by the public. 


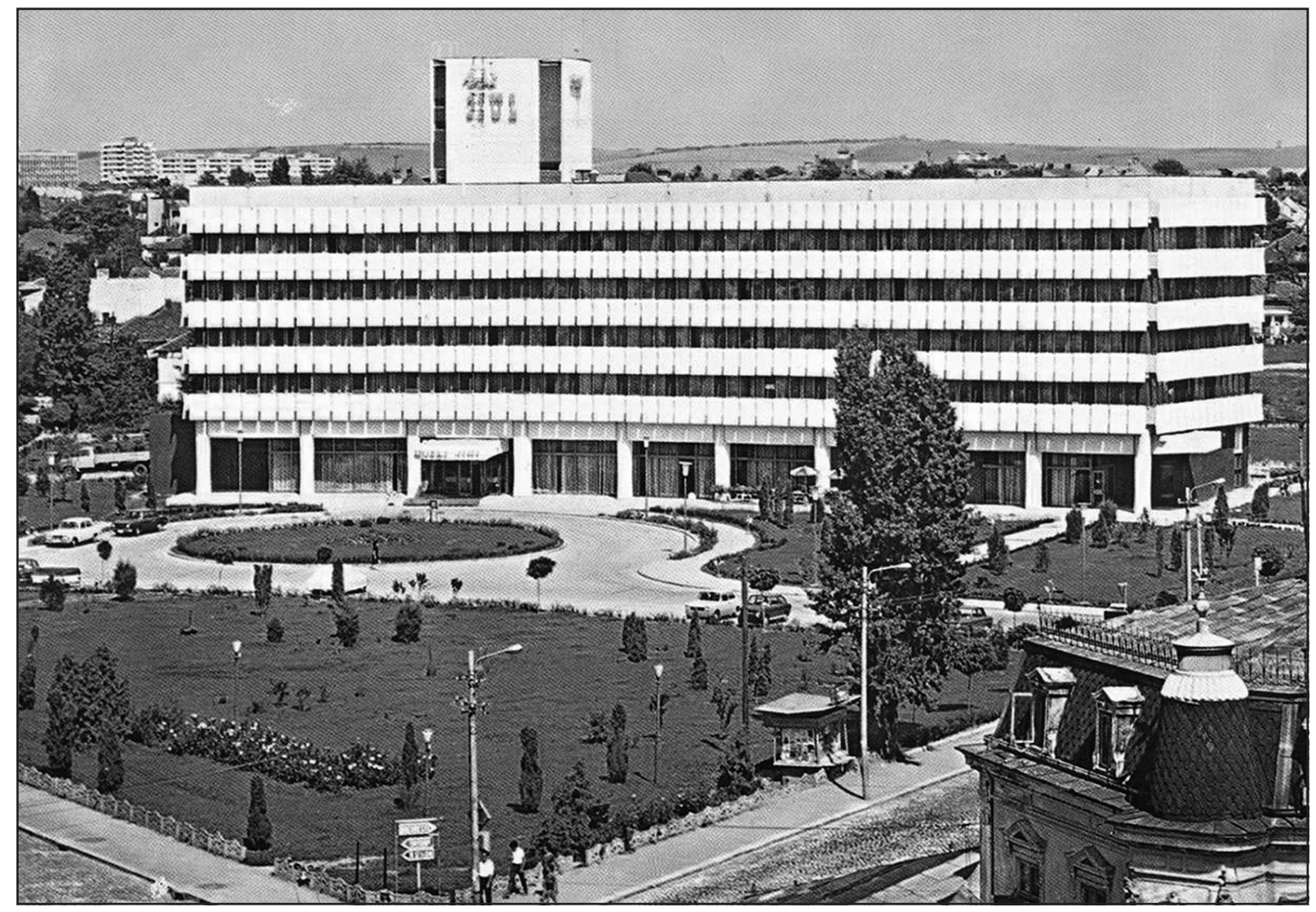

Figure 7: "Jiul" Hotel, Craiova, in its original form (built in the 1970s).

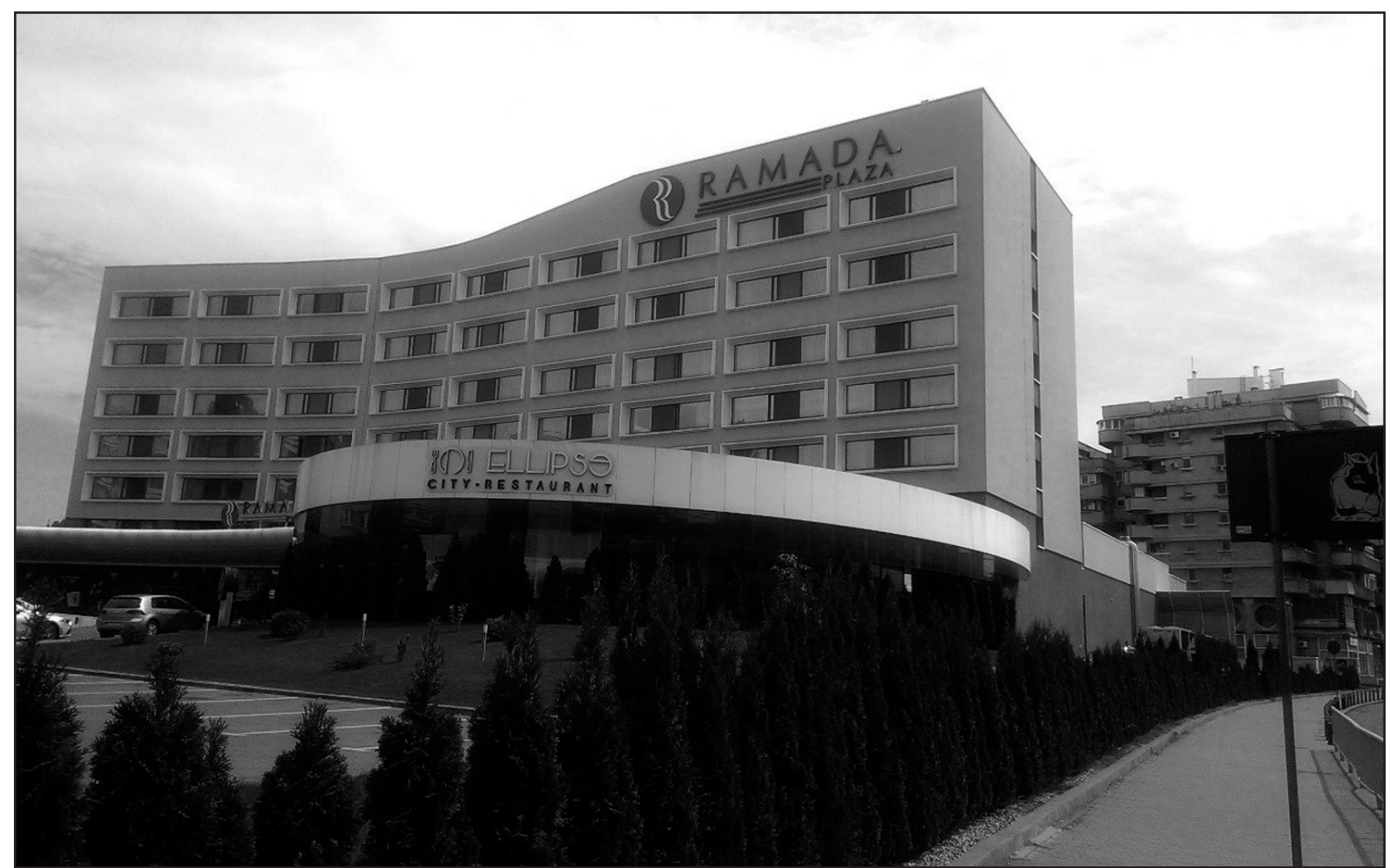

Figure 8: "Jiul" Hotel (Craiova) as today's "Ramada Plaza". The "Ramada" international hotel chain has recently bought the "Jiul", revamping it with a couple of contemporary features, such as a new facade. 

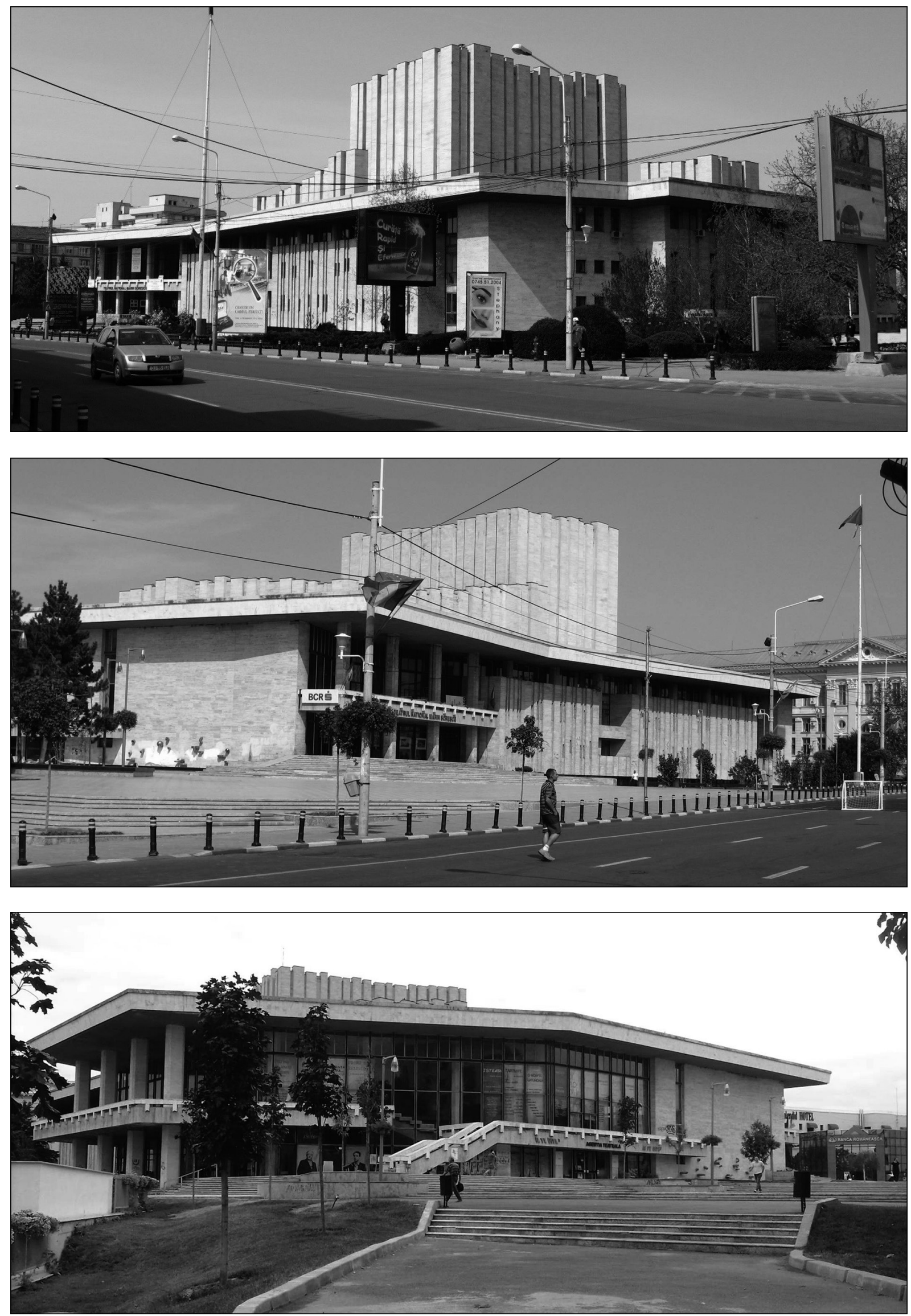

Figure 9, 10, 11: The National Theatre building, Craiova, erected 1969-1974 and displaying an unaltered, original facade. The area is very popular with the citizens of Craiova. 

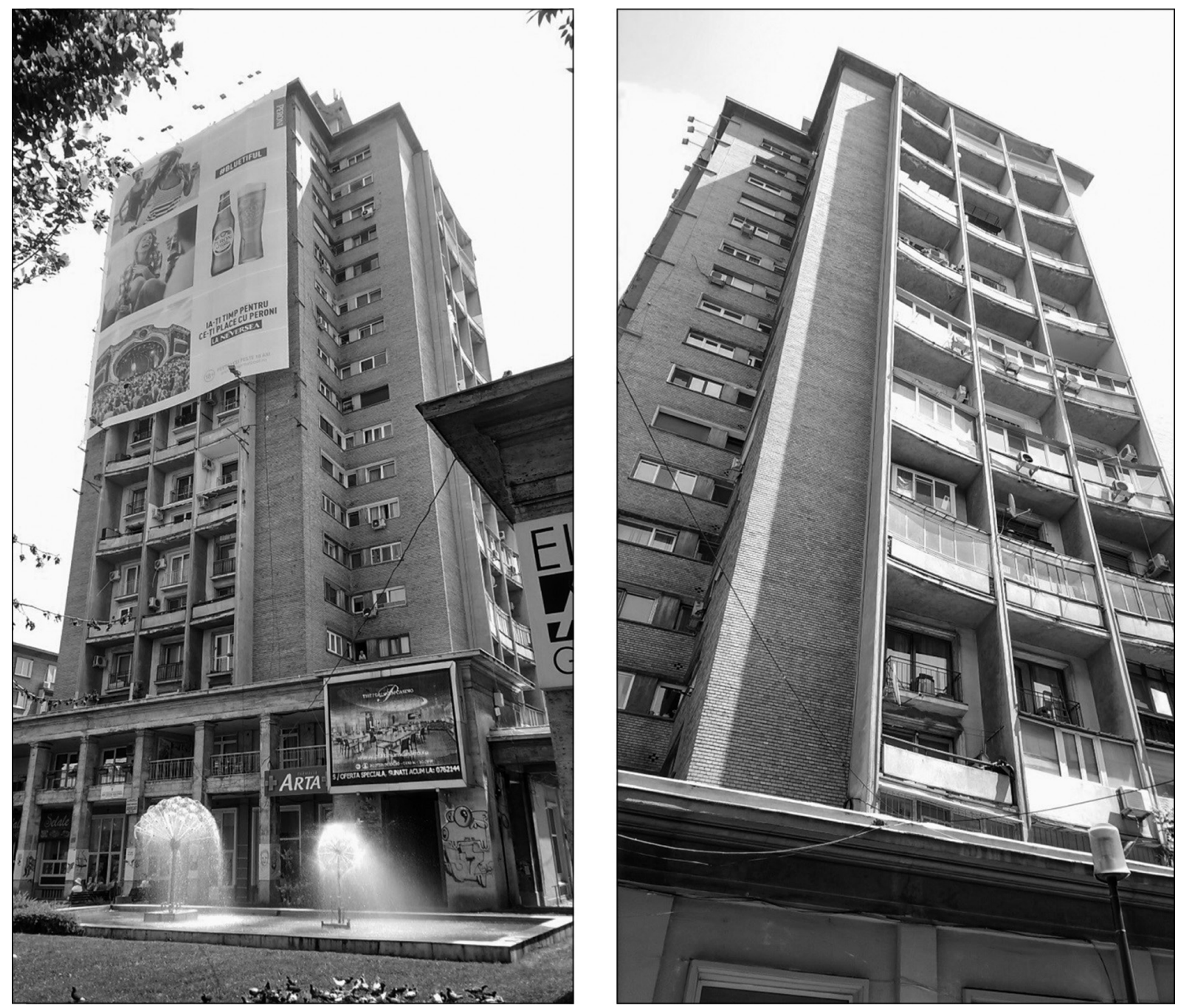

Figure 12, 13: "Gioconda" tower block, Bucharest, in 2 recent photos, showing very few marks of post-communist interventions. Built in 1959 as one of the highest apartment blocks in Bucharest up to that date, the building faces a high risk of collapse in case of a powerful earthquake. This is one of the reasons for which it has become a low-income block of flats, with apartment prices and rents being relatively low. Aside from a partial reinforcement of its load-bearing structure, the building has not been renovated/rehabilitated/revamped, as its seismic risk is jeopardising such potential investments, from a financial point of view. Some of the original windows and frames have been replaced by newer, more efficient ones. There are numerous cracks that can be seen on the facades. Some of the surfaces are cladded with travertine stone (an expensive material), but are badly upkept. Some surfaces are covered with graffiti. The advertising mesh is hindering the access of natural light inside the rooms that are behind it.

\section{REFERENCES}

[1] Tulbure, Irina (2016) Arhitectură și urbanism în România anilor 1944-1960: constrângere şi experiment [Architecture and urbanism in Romania from 1944 to 1960: constraint and experiment], Bucharest, Ed. Simetria, pp. 184-202.

[2] Armaș, Iuliana, "Earthquake Risk Perception in Bucharest, Romania", Risk Analysis, vol. 26, nr. 5/2006.

[3] Tulbure, Irina (2016) idem, pp. 232-233. 
[4] Tulbure, Irina, “Teatrul Naţional din Craiova (1969-1974)" [Craiova National Theatre (1969-1974)], Zeppelin, https://e-zeppelin.ro/istoria-acum/teatrul-national-din-craiova-1969-1974/text-critic-irina-tulbure/.

[5] Figure 1: https://www.facebook.com/ImaginiBucuresti/photos /a.1578916568999146/2351692475054881/?type=3\&theater.

[6] Figure 2: personal archive.

[7] Figure 3: https://adevarul.ro/economie/imobiliare/magazinul-cocor-de-a-lungul-timpului-7_50b3582f7c42d5a663a3b0e9/2_50a8d4d07c42d5a663741feb.html.

[8] Figure 4: personal archive.

[9] Figure 5: http://sanuuitam.blogspot.com/2017/08/din-banie-3.html.

[10] Figure 6: personal archive.

[11] Figure 7: https://craiovadeieri.wordpress.com/2018/02/02/din-trecutul-unui-loc-cu-istorievalea-vlaicii/.

[12] Figure 8: personal archive.

[13] Figure 9, 10: personal archive.

[14] Figure 11, 12, 13: personal archive. 